\title{
Late Famennian stromatoporoids from Dębnik Anticline, southern Poland
}

Paweł Wolniewicz

Acta Palaeontologica Polonica 54 (2), 2009: 337-350 doi:http://dx.doi.org/10.4202/app.2007.0096

Famennian Stromatoporoidea from the Quasiendothyra communis Foraminiferal Zone and slightly younger strata from the Dębnik anticline, southern Poland, form a succession of three consecutive assemblages. Assemblages 1 and 3 consist of representatives of the order Clathrodictyida, while assemblage 2 is dominated by the order Labechiida. The clathrodictyids are represented by the genus Gerronostroma, and labechiids are represented by the genus Stylostroma. Species assigned here to the genus Gerronostroma show a network of amalgamated pillars in the central part of the columns, a feature regarded by previous authors as typical of the genus Clavidictyon. Two new species, Stylostroma multiformis sp. nov. and Gerronostroma raclaviense sp. nov., are described. Stromatoporoids from southern Poland differ from the Famennian fauna of western Europe, showing affinity to eastern European and Siberian Stromatoporoidea.

Key words: Porifera, Stromatoporoidea, Labechiida, Clathrodictyida, Gerronostroma, Stylostroma, ontogeny, phases, statistics, Famennian, Poland.

Paweł Wolniewicz [pawelw@amu.edu.pl], Uniwersytet im. Adama Mickiewicza, Instytut Geologii, ul. Maków Polnych 16, PL-61-606 Poznań, Poland.

This is an open-access article distributed under the terms of the Creative Commons Attribution License (for details please see creativecommons.org), which permits unrestricted use, distribution, and reproduction in any medium, provided the original author and source are credited. 